\title{
Internal morphology and germination of sunflower seeds ${ }^{1}$
}

\author{
Cartiane Rubshirley Macêdo da Rocha ${ }^{2}$, Vanessa Neumann Silva ${ }^{3 *}$, \\ Silvio Moure Cicero ${ }^{2}$
}

\begin{abstract}
The use of high quality seeds is one of the important factors to increase productivity in areas cultivated with sunflower. The aim of this study was to investigate the relationship between internal morphology and germination of sunflower seeds with the X-ray test and computer-aided X-ray imaging analysis with the software Tomato Analyzer ${ }^{\circledR}$, and check whether or not this relationship changes after a period of seed storage under different environmental conditions. For this purpose, five lots of sunflower seeds from cultivar Catissol 01 were used. They were evaluated during two experimental periods: at 0 and 4 months after storage; the first evaluation was performed to characterize the lots; after that, the seeds were stored in two environments, cold and dry chamber $\left(10{ }^{\circ} \mathrm{C}\right.$ and $30 \%$ relative air humidity) and non-controlled environment. The seed moisture content was determined and, after that, the seeds were submitted to the X-ray and germination tests. The X-ray analysis allowed the visualization of seed internal structure as well as the study between seed morphology and germination; the greater embryo size, in general, does not provide greater potential for seed germination; regardless of the storage conditions for the four-month period, there was no reduction in the area of the embryo.
\end{abstract}

Index terms: Helianthus annus, images, X-ray.

\section{Morfologia interna e germinação de sementes de girassol}

\begin{abstract}
RESUMO- A utilização de sementes de alta qualidade é um dos fatores preponderantes para aumentar a produtividade de áreas cultivadas com girassol. Objetivou-se investigar a relação existente entre a morfologia interna de sementes de girassol e a germinação, com a utilização do teste de raios X e análise computadorizada das imagens radiográficas com o software Tomato Analyzer $^{\circledR}$, e verificar se essa relação se altera após o armazenamento das sementes em diferentes condições ambientais. Foram utilizados cinco lotes de sementes de girassol cultivar Catissol 01, avaliados aos 0 e 4 meses de armazenamento; na primeira época foi realizada a caracterização dos lotes; após, foi realizado o armazenamento das sementes em duas condições de ambientes, câmara fria e seca $\left(10^{\circ} \mathrm{C}\right.$ e $30 \%$ umidade relativa do ar) e ambiente não controlado. As sementes foram avaliadas quanto ao teor de água e submetidas ao teste de raios $\mathrm{X}$ e de germinação. A análise radiográfica das sementes permitiu a visualização da estrutura interna da semente e o estudo entre a morfologia e a germinação; a maior área ocupada pelo embrião, de forma geral, não conferiu maior germinação para as sementes. Independentemente das condições em que as sementes permaneceram armazenadas durante quatro meses, não houve redução da área ocupada pelo embrião.
\end{abstract}

Termos para indexação: Helianthus annuus L., imagens, raios X.

\section{Introduction}

Sunflower cultivation has increased in recent years mainly because of the need of raw materials for the production of biofuels; this is one of the most important oilseed crops in the world today. The seeds of this species have around $47 \%$ of lipids in their composition, which can be converted into oil, both for domestic use and for biofuel production (Gazzoni, 2005).

To increase the productivity of areas with sunflower crops,

${ }^{1}$ Submitted on 08/16/2013. Accepted for publication on 12/04/2013. ${ }^{2}$ Departamento de Produção Vegetal, USP/ESALQ, Caixa Postal 9, 13418-900 Piracicaba, SP, Brasil. one of the aspects that should be considered is the use of high quality seeds. Several factors interferes obtaining high quality seeds; some occur during seed formation and development in the field, while others occur when during the harvest and post harvest stages. In particular, the flowering of sunflower seeds is uneven, and pollination is entomophilous. Thus, seeds may occur at different maturity stages during harvest and, consequently, there may be differences in their internal morphology, with probable consequences for the physiological potential of seeds. The

${ }^{3}$ Universidade Federal do Pampa, Campus de Itaqui, 97650-000 - Itaqui, RS, Brasil.

* Corresponding author<vnpel@yahoo.com.br> 
conditions prevailing during seed formation affect the quality of the seeds produced and, thus, the establishment of the crop in the next cultivation period (Ahmad, 2001).

Seeds at different maturity stages are different in size and in the amount of accumulated reserve substances. Research on sunflower seeds has indicated that seed size influences germination (Torres and Martinez, 1990) and seedling emergence in the field (Ahmad, 2001).

Seed size can be measured manually; however, the relationship between morphology and germination can be better understood by means of procedures used to measure embryo size and the area filled by the reserve tissues of seeds.

One way to examine the internal morphology of seeds is by analyzing $\mathrm{X}$-ray images. The $\mathrm{X}$-ray test has been shown effective for analysis of seeds of various species, such as tomato (Silva et al., 2013), eggplant (Silva et al., 2012), castor beans (Kobori et al., 2012), sweet corn (Gomes Junior and Cicero, 2012a), among others. Another advantage is that it is a nondestructive technique, allowing these seeds to be used for other purposes; moreover, this test provides information on the occurrence of malformation of seeds and empty seeds, and allows the visualization of the position and extent of the damage occurring in the embryonic axis (Cicero et al., 1998; Carvalho et al., 1999), which may interfere with seed viability.

Through X-ray analysis, it is possible to measure the internal parts of seeds and calculate embryo size; the latter can be defined by the degree of development of the embryo and the free space in the internal seed cavity (Marcos-Filho et al., 2010). This space is described in the literature as empty or free space, and it is an expression used for the occurrence of empty spaces between the embryo and the endosperm or between the seed contents and the seed coat. It can occur in different parts of the seed, but it usually occurs around the embryo and it was determined for the first time for tomato seeds (Liu et al., 1993).

The measurement of free space within the seed and, for that matter, embryo size can be determined by analysis of X-ray images with the software Tomato Analyzer $\AA$. While carrying out studies with cotton and pumpkin seeds, Marcos - Filho et al. (2010) found that the software Tomato Analyzer ${ }^{\circledR}$ was sensitive to consistently evaluate the degree of development of seed embryos and suggested that the procedure is promising for seeds of other species with similar structure to those studied in their research. Likewise, Gomes Junior et al. (2013) were successful in using the software for analysis of the internal morphology of cucumber seeds. However, this method has been studied for a only few species to date, and further research is needed on the subject.

In this sense, the objective of the present study to verify the relationship between the internal morphology of sunflower seeds and germination, using the X-ray tests and computeraided X-ray imaging analysis with the software Tomato Analyzer ${ }^{\circledR}$ and check if this relationship changes after the seeds are stored for a particular period of time under different environmental conditions.

\section{Materials and Methods}

The research was conducted in the Laboratories of Image Analysis and Seeds Analysis, Department of Plant Production (LPV), College of Agriculture "Luiz de Queiroz" (ESALQ), University of São Paulo (USP), in the city of Piracicaba, state of São Paulo. Five lots of sunflower seeds (cultivar Catissol 01) were used. The experiment lasted for four months with two evaluation periods ( 0 and 4 months); the lots were characterized in the first period; then the seeds were stored in Kraft paper bags, under two environmental conditions (cold and dry chamber $-10{ }^{\circ} \mathrm{C}$ and $30 \%$ relative air humidity) and in an non-controlled environment.

Before the evaluations of the second period, seed moisture content was homogenized because the seeds had been exposed to different storage conditions. Thus, in the second evaluation period, the seeds that had been stored in the cold and dry chamber were maintained in the non-controlled environment for approximately ten days before the tests were performed. This fact is crucial for performing the tests, because the homogeinity of seed moisture content is essential for standardization and comparability of results (Marcos-Filho, 1999).

Seed moisture content was determined by oven-drying at $105^{\circ} \mathrm{C}$ for 24 hours (Brasil, 2009) in two samples. The results were expressed as mean percentage (wet basis) per lot.

$X$-ray test: this test was conducted with four replications of 50 seeds, which were placed on double-sided tape on a plastic transparent sheet; the seeds were numbered according to their position on the sheet, so that they could be identified in subsequent measurements. Then, the transparent sheet was placed inside a Faxitron MX-20 DC-12 digital X-ray system, connected to a Core 2 Duo computer $(3: 16 \mathrm{GHz}, 2 \mathrm{~GB}$ RAM, 160 GB Hard Disk) and 17-inch MultiSync ${ }^{\circledR}$ LCD1990SX monitor, and kept $28.6 \mathrm{~cm}$ apart from the source of radiation emission for 20 seconds. After the images were generated, they were saved on a hard disk drive for subsequent analysis. The seeds were removed from the sheet and transferred to an acrylic tray with individual cells, and numbered in the same order they had in the X-ray images. After that, the seeds were submitted to the germination test, as described below.

Germination test: it was performed on a paper towel substrate moistened with distilled water in the ratio of 1 : 2.5 (paper: water). The previously numbered seeds were distributed on two sheets of paper towel (in the upper third 
of the substrate to enable the development of individual seedlings) and covered with another sheet. The wrapped seeds were placed in the incubator at $25^{\circ} \mathrm{C}$ and the evaluation was performed on the fourth day after sowing (Brasil, 2009). The normal and abnormal seedlings and the dead seeds were removed from the paper towel and photographed with a Nikon D10 digital camera connected to the computer. The images were saved on the hard disk drive for subsequent analysis.

X-ray imaging of the seeds was analyzed with the software Tomato Analyzer ${ }^{\circledR}$ by determining the seed area, the free space within the seed and the ratio between these areas (Marcos-Filho et al., 2010). The calculation was performed by subtracting the free space area from the total seed area to obtain the area filled by the embryo tissues. Also, calculations were performed for the mean value of the seed cavity area filled by the embryo of each lot, for the overall mean of all lots, as well as for the standard deviation. Based on these values and on the morphology of seed parts, the seeds were classified into one of the three categories below:

a) Category 1: seeds whose area filled by the embryo was smaller than the mean minus one standard deviation; b) Category 2: seeds whose values of the area filled by the embryo ranged between the mean minus one standard deviation and the mean; Category 3: seeds whose area filled by the embryo was larger than the mean.

The analysis of results was performed by comparing the $\mathrm{X}$-ray images with the respective images of normal or abnormal seedlings and dead seeds used in the germination test.

\section{Results and Discussion}

In the first evaluation period, seed moisture content ranged from $9.5 \%$ to $10.6 \%$ for all lots. According to Simak (1991), the lower the seed moisture content, the higher the optical density, which enables greater differentiation of the internal parts of the seeds as seen in the X-ray images.

$\mathrm{X}$-ray imaging analysis with the software Tomato Analyzer ${ }^{\circledR}$ allowed the measurement of internal free areas of sunflower seeds and, thus, the determination of embryo size, confirming the results of Marcos Filho et al. (2010), which indicate that the software is a feasible choice for evaluating seeds of several species, as also noted by Gomes Junior et al. (2012b) for watermelon seeds. This finding is of great importance for the field of seed analysis, because computeraided imaging analysis is currently the most advanced method to obtain highly accurate results (Dell'Áquila, 2009).

According to the results, it was observed that the embryo filled more than $60 \%$ of the internal seed area for all lots (Table 1); examples of seeds with differences in the internal area filled by the embryo may be seen in Figure 1. During the $\mathrm{X}$-ray tests, the seeds are submitted to a radiation beam, which forms an image as it goes through the seeds and reaches the film. Such image is characterized by different grayscale tones, and X-ray absorption in different amounts by the tissues of the seeds depends on their structure, composition and density, as well as the period of exposure to radiation (ISTA, 2004).

Table 1. Area (\%) filled by the embryo of sunflower seeds, cultivar Catissol, compared with the total seed area (mean for each lot) and values of the categories used for data analysis in the first and second storage period.

\begin{tabular}{|c|c|c|c|c|c|}
\hline Lot & $\begin{array}{c}\text { Area } \\
\text { (Embryo) }\end{array}$ & $\begin{array}{l}\text { Standard } \\
\text { Deviation }\end{array}$ & \multicolumn{3}{|c|}{$\begin{array}{c}\text { Category } \\
\text { (area of the embryo) }\end{array}$} \\
\hline \multicolumn{3}{|c|}{ First period (0 months) } & 1 & 2 & 3 \\
\hline 1 & 63 & 5 & \multirow{6}{*}{$<57$} & \multirow{6}{*}{$57-63$} & \multirow{6}{*}{$>63$} \\
\hline 2 & 62 & 5 & & & \\
\hline 3 & 61 & 5 & & & \\
\hline 4 & 62 & 6 & & & \\
\hline 5 & 62 & 5 & & & \\
\hline Mean & 62 & 5.2 & & & \\
\hline \multicolumn{6}{|c|}{ Second period (4 months) - Non-controlled environment } \\
\hline 1 & 64 & 5 & \multirow{6}{*}{$<57$} & \multirow{6}{*}{$57-62$} & \multirow{6}{*}{$>62$} \\
\hline 2 & 63 & 5 & & & \\
\hline 3 & 63 & 5 & & & \\
\hline 4 & 64 & 5 & & & \\
\hline 5 & 63 & 5 & & & \\
\hline Mean & 64 & 5 & & & \\
\hline \multicolumn{6}{|c|}{ Second period (4 months) - Controlled environment } \\
\hline 1 & 63 & 4 & \multirow{6}{*}{$<58$} & \multirow{6}{*}{$58-63$} & \multirow{6}{*}{$>63$} \\
\hline 2 & 62 & 5 & & & \\
\hline 3 & 62 & 5 & & & \\
\hline 4 & 63 & 6 & & & \\
\hline 5 & 62 & 5 & & & \\
\hline Mean & 62 & 5 & & & \\
\hline
\end{tabular}

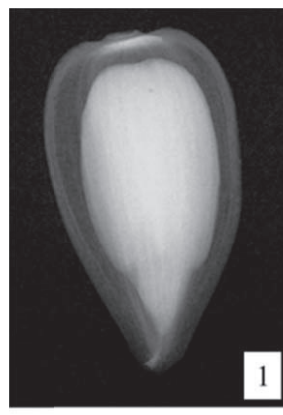

$<58$

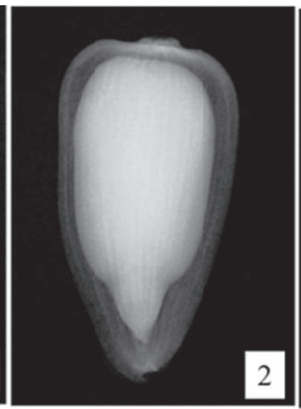

$58.01-63$

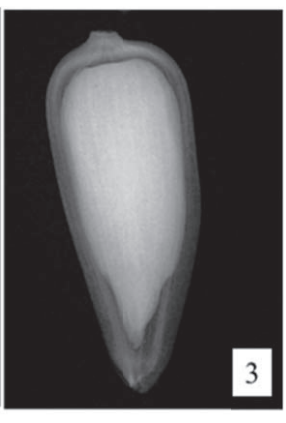

$>63.01$
Figure 1. Examples of sunflower seeds, cultivar Catissol, lot 1 , with differences in the internal area filled by the embryo, in categories 1-3. 
The results in Table 1 also show that both at the beginning of the experiment, and after four months of storage, regardless of seed storage conditions in this period, there was no reduction in the area filled by the embryo, something that could have occurred depending on the progress of the deterioration process. After four months of storage, seed moisture content was on average around 7 and $8 \%$ for the controlled and noncontrolled environments, respectively. It was observed that these values were lower than those of the first period, and seed moisture content did not increase, a fact that could have accelerated deterioration reactions.

After seeds have reached physiological maturity, they start to suffer these deteriorative reactions, which lead to loss of germination capacity. However, several factors can affect this process, e.g., environmental conditions, especially high temperatures and relative air humidity, as they can accelerate catabolic reactions, leading to the reduction of stored seed reserves, as well as other injuries that may reduce physiological potential, such as denaturation of enzymes, among others.

The results of this research showed that the period of seed storage did not produce significant changes in the embryo or in the seed reserves when the X-ray images were analyzed. Catabolic reactions may have occurred slowly, as the seeds had reduced moisture content, even in an environment with non-controlled conditions.

It can also be noted that in more than half of the seeds from each lot, the internal area filled by the embryo was above $60 \%$ (Tables 1 and 2), both at the beginning of the experiment and after four months of storage, in most cases, except for lots 1 and 2 when stored in a controlled environment and lot 3 after storage under non-controlled conditions.

As for embryo size of the seeds and germination, there was little difference between the categories under study for most lots, except for lot 4 in the first evaluation period (Table 2); thus, it can be inferred that the larger embyo size offered higher germination potential for lot 4 only, but it was not influential for the other lots. Similar results were observed for seeds of tomato (Silva et al., 2013), and eggplant (Silva et al., 2012). These researchers found that seeds whose area filled by the embryo is larger do not always have higher germination potential.

Table 2. Seed percentage (S) in each internal morphology category (C) and normal seedlings (NS) obtained in the germination test of sunflower seeds stored in the controlled environment $(\mathrm{CE})$ and the non-controlled environment (NCE).

\begin{tabular}{|c|c|c|c|c|c|c|c|c|c|}
\hline \multirow{4}{*}{ Lot } & \multicolumn{9}{|c|}{ Storage period (months) } \\
\hline & \multirow{2}{*}{\multicolumn{3}{|c|}{0}} & \multicolumn{6}{|c|}{4} \\
\hline & & & & \multicolumn{3}{|c|}{ NCE } & \multicolumn{3}{|c|}{$\mathrm{CE}$} \\
\hline & $\mathrm{C}$ & S (\%) & NS (\%) & $\mathrm{C}$ & S (\%) & NS (\%) & $\mathrm{C}$ & $\mathrm{S}(\%)$ & NS (\%) \\
\hline \multirow{3}{*}{1} & 1 & 12 & 100 & 1 & 15 & 48 & 1 & 63 & 94 \\
\hline & 2 & 28 & 96 & 2 & 31 & 51 & 2 & 25 & 94 \\
\hline & 3 & 60 & 91 & 3 & 54 & 39 & 3 & 22 & 72 \\
\hline \multirow{3}{*}{2} & 1 & 18 & 99 & 1 & 16 & 91 & 1 & 18 & 86 \\
\hline & 2 & 30 & 99 & 2 & 36 & 85 & 2 & 27 & 96 \\
\hline & 3 & 52 & 92 & 3 & 48 & 82 & 3 & 55 & 95 \\
\hline \multirow{3}{*}{3} & 1 & 21 & 99 & 1 & 20 & 93 & 1 & 21 & 95 \\
\hline & 2 & 38 & 96 & 2 & 31 & 87 & 2 & 27 & 100 \\
\hline & 3 & 41 & 99 & 3 & 49 & 79 & 3 & 52 & 99 \\
\hline \multirow{3}{*}{4} & 1 & 18 & 68 & 1 & 15 & 28 & 1 & 17 & 74 \\
\hline & 2 & 23 & 72 & 2 & 26 & 34 & 2 & 18 & 80 \\
\hline & 3 & 59 & 83 & 3 & 59 & 40 & 3 & 65 & 79 \\
\hline \multirow{3}{*}{5} & 1 & 13 & 99 & 1 & 18 & 84 & 1 & 15 & 97 \\
\hline & 2 & 34 & 94 & 2 & 31 & 19 & 2 & 33 & 92 \\
\hline & 3 & 53 & 93 & 3 & 51 & 69 & 3 & 57 & 97 \\
\hline
\end{tabular}

In this context, it is important to note that there were small differences between the categories in the values for the area of the embryo, which might explain the lack of association with potential for seed germination. Similar results were found for seeds of tomato (Silva et al., 2013) and eggplant (Silva et al., 2012).

The seeds of the different categories yielded both normal and abnormal seedlings and dead seeds, regardless of embryo size. Figure 2 shows an example of sunflower seeds of lot 1 , classified in different morphology categories, which produced normal seedlings.

After four months of storage, both in non-controlled and controlled environments, there was a similar behavior to the 
one observed at the beginning of the study: differences in germination potential between different categories of seed morphology were small, and germination was favored by larger embryo size only in lots 2 and 4.

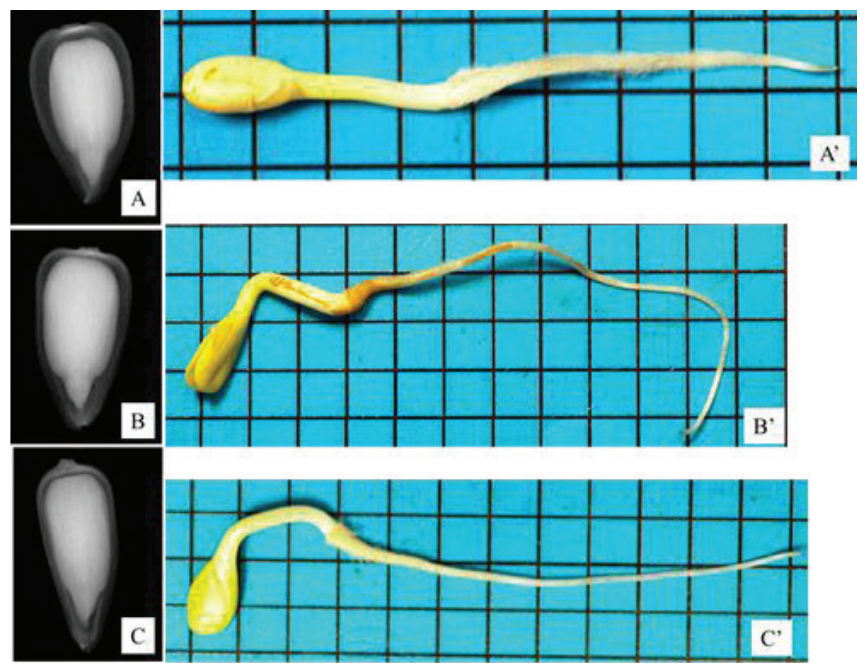

Figure 2. Examples of sunflower seeds, cultivar Catissol, lot 1, morphology categories 1 (A), 2 (B) and 3 (C) and their respective normal seedlings (A', B' and $\left.C^{\prime}\right)$.

The analysis of the effect of length and storage condition showed that there were no differences in the percentage of seeds found in each morphology category, which suggests that the conditions used did not change the internal morphology of seeds. However, it is observed that although there was no change in the internal morphology of the stored seeds, there was a greater reduction of the physiological potential for the seeds stored in the non-controlled environment, showing the progress of the decay process of these seeds. Studying the effect of storage on the germination of sunflower seeds, Grisi and Santos (2007) found that germination potential of seeds remained high until approximately 120 days after the start of storage, but this varied across the cultivars used and the levels of vigor.

\section{Conclusions}

$\mathrm{X}$-ray imaging analysis revealed the internal structure of the seeds;

Larger embryos, in general, do not provide higher germination potential for sunflower seeds;

Regardless of the storage conditions of the seeds in the four-month period, there was no reduction of the area of the embryo.

\section{References}

AHMAD, S. Environmental effects on seed characteristics of sunflower. Journal of Agronomy and Crop Science, v.187, n.3, p. 213-216, 2001. http:// onlinelibrary.wiley.com/doi/10.1046/j.1439-037x.2001.00523.x/abstract

BRASIL. Ministério da Agricultura, Pecuária e Abastecimento. Regras para análise de sementes. Ministério da Agricultura, Pecuária e Abastecimento. Secretaria de Defesa Agropecuária. Brasília, 2009. 395p. http://www.bs.cca. ufsc.br/publicacoes/regras\%20analise \%20sementes.pdf

CARVALHO, M.L.M.; AELST, A.C.; ECK, J.W; HOEKSTRA, F.A. Pre-harvest stress cracks in maize (Zea mays L.) kernels as characterized by visual, X-ray and low temperature scanning electron microscopical analysis: effect on kernel quality. Seed Science Research, v.9, n.3, p.227-236, 1999. http://journals.cambridge.org/action/ displayAbstract;jsessionid=7D867B378C148BDC8381DD8580748DA5. journals? fromPage $=$ online $\&$ aid $=693516$

CICERO, S.M.; HEIJDEN, G.W.A.M.; VAN DER BURG, W.J.; BINO, R.J. Evaluation of mechanical damages in seeds of maize (Zea mays L.) by X-ray and digital imaging. Seed Science and Technology, v.26, n.3, p.603-612, 1998.

DELL'AQUILA, A. Development of novel techniques in conditioning, testing and sorting seed physiological quality. Seed Science and Technology, v.37, n.3, p. 608-624, 2009. http://www.ingentaconnect.com/content/ista/ sst $/ 2009 / 00000037 / 00000003 / a r t 00010$

GAZZONI, L.D. Óleo de girassol como matéria-prima para biocombustíveis. In: LEITE, R.M.V.B.C.; BRIGHENTI, A.M.; CASTRO, C. (Ed.). Girassol no Brasil, Londrina: Embrapa Soja, 2005, p. 145-162.

GOMES JUNIOR, F.G.; CICERO, S.M. X-Ray analysis to assess mechanical damage in sweet corn seeds. Revista Brasileira de Sementes, v. 34, n.1, p.078-085, 2012a. http://www.scielo.br/scielo.php?pid=S0101$31222012000100010 \&$ script $=$ sci $\_$arttext

GOMES JUNIOR, F.G.; YAGUSHI, J.T.; BELINI, U.L.; TOMAZELLOFILHO, M. X-ray densitometry to assess internal seed morphology and quality. Seed Science and Technology, v. 40, n.1, p. 102-107, 2012b. http://www. ingentaconnect.com/content/ista/sst/2012/00000040/00000001/art00011

GOMES JUNIOR, F.G.; CHIQUITO, A.A.; MARCOS- FILHO, J. Semiautomated assessment of the embryonic area of cucumber seeds and its relationship to germination and seedling length. Journal of Seed Science, v.35, n.2, p.183-189, 2013.

GRISI, P.; SANTOS, C.M. Influência do armazenamento, na germinação das sementes de girassol. Horizonte Cientifico, v. 1, n.1, p. 1-14, 2007. http:// www.seer.ufu.br/index.php/horizontecientifico/article/view/3890/2895

ISTA. International Rules for Seed Testing Association, Zurich, 174p. 2004.

KOBORI, N.N.; CICERO, S.M.; MEDINA, P.F. Teste de raios X na avaliação da qualidade de sementes de mamona. Revista Brasileira de Sementes, v. 34, n.1, p.125-133, 2012. http://www.scielo.br/scielo.php?script=sci arttext\&pid=S0101-31222012000100016

LIU, Y.; VAN DER BURG, W.J.; AARTSE, J.W.; VAN ZWOL, R.A.; JALINK, H.; BINO, R.J. X-ray studies on changes in embryo and endosperm morphology during priming and imbibition of tomato seeds. Seed Science Research, v.3, n.3, p.171-178, 1993. http://journals.cambridge.org/action/ displayAbstract? fromPage $=$ online $\&$ aid $=1353132$ 
MARCOS-FILHO, J. Testes de vigor: importância e utilização. In: KRYZYZANOWSKI, F.C.; VIEIRA, R.D.; FRANÇA-NETO, J.B. (Ed.). Vigor de sementes: conceitos e testes. Londrina: Abrates, 1999, cap. 3, p. 1-24.

MARCOS-FILHO, J., GOMES-JUNIOR, F.G., BENNETT, M.A., WELLS, A.A., STIEVE, S. Software Tomato Analyzer para a determinação do tamanho do embrião em sementes radiografadas. Revista Brasileira de Sementes, v.32, n.2, p.146-153. 2010. http://www.scielo.br/scielo.php?script=sci arttext\&pid=S0101-31222010000200018

SILVA, V.N.; CICERO, S.M.; BENNETT, M. Relationship between eggplant seed morphology and germination. Revista Brasileira de Sementes, v. 34, n. 4, p. 597 - 604, 2012. http://www.scielo.br/scielo.php?pid=S010131222012000400010\&script=sci_arttext
SILVA, V.N.; CICERO, S.M.; BENNETT, M. Associations between X-ray visualised internal tomato seed morphology and germination. Seed Science and Technology, v. 41, n.2, p. 225-234, 2013. http://www.ingentaconnect. com/content/ista/sst/2013/00000041/00000002/art00005

TORRES, M.; MARTINEZ, C.J. Effect of seed size on the germination and vigour of sunflower. Journal of Agricultura Mediterranea, v. 120, n.2, p. 220-225, 1990. http://www.cabdirect.org/abstracts/19900737734. $\mathrm{html}$;jsessionid=946156E013BD744209E44BE012E73AE4

SIMAK, M. Testing of forest tree and shrub seeds by X-radiography. In: GORDON, A.G.; GOSLING, P.; WANG, B.S.P. (Ed.) Tree and shrub seed handbook. Zurich: ISTA, 1991. p.1-28. 